\title{
Depth distribution of zooplankton in relation to limnological gradients under different stratification and interannual regimes in a deep, tropical crater lake
}

\author{
Peter O. Sanful ${ }^{1, *}$, Samuel Aikins ${ }^{2}$ and Robert E. Hecky ${ }^{3}$ \\ ${ }^{1}$ Department of Fisheries and Water Resources, School of Natural Resources, University of Energy and Natural Resources (UENR), \\ P.O. Box 214, Sunyani, Ghana \\ ${ }^{2}$ Department of Theoretical and Applied Biology, Kwame Nkrumah University of Science and Technology (KNUST), Kumasi, Ghana \\ ${ }^{3}$ Biology Department and Large Lakes Observatory, University of Minnesota-Duluth, 2205 East Fifth Street, Duluth, MN 55812, USA
}

Received: 10 March 2017; Accepted: 24 July 2017

\begin{abstract}
Zooplankton vertical distribution was studied in Lake Bosumtwi to understand how spatial and temporal variations in the water column affected diurnal and nocturnal patterns. Biweekly samples were collected for 24 consecutive months at the deepest point from 2005 to 2006 . Water column properties shaping habitat suitability, namely temperature, light intensity, dissolved oxygen and phytoplankton biomass, varied markedly with depth but less with season. Most zooplankton stayed in the epilimnion continuously and their distribution was unaltered by lake stratification, mixing and restratification. Species dwelt permanently in the epilimnion without any necessity to migrate. Reduced water column variability and resultant weak selective pressures suppressed greater dispersion of species. Chaoborus ceratopogones (Theobald) was the main invertebrate predator and performed upward and downward movements on a diel cycle. Competing prey species overlapped extensively in spatial and temporal degree of habitat use. Chaoborus, however, segregated in deep water during the day, thereby minimizing prey vulnerability and promoting coexistence among predators and prey. During night-time residence, prey species may be exposed to increased predation risk from Chaoborus but gains in reproductive potential in warm, food-rich surface waters may offset losses to mortality. Our results suggest that high degree of habitat constancy and consequently weak selective pressures contributed to the lowered behavioural responses of zooplankton. The persistently skewed distribution of zooplankton is adaptive to predation and competition and promotes species coexistence. This behaviour will optimize growth and reproductive benefits over the cost of descent to suboptimal conditions in deep water.
\end{abstract}

Keywords: Lake Bosumtwi / Mesocyclops bosumtwii / vertical distribution / tropical / water column parameters

\section{Introduction}

Compared to shallow lakes, deep thermally stratified tropical lakes exhibit sharp vertical gradients in physicochemical parameters that create depth habitats of variable quality for zooplankton species (MacIntyre, 2012). Variation in temperature, dissolved oxygen, food concentration, light intensity, competition and predation risk with depth define habitat suitability and influence habitat choice of zooplankton populations (Leibold, 1990; Andersen and Nival, 1991; Winder et al., 2003; Stratton and Kessler, 2007; Khalifa et al., 2015). The distribution of zooplankton often is a response to the spatio-temporal dynamics of the physical environment within which they live (Wetzel, 2001; Hansson et al., 2007).

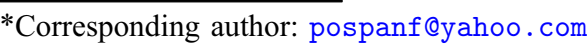

By contrast, the lack of physical partitioning in shallow unstratified lakes simplifies the aquatic habitat (Burks et al., 2002) and result in uniform dispersion of zooplankton (Mavuti, 1992). Stratified waterbodies therefore offer greater scope of discrete depth-habitats for diverse zooplankton to inhabit (Bini et al., 2001). The observed distribution patterns are the outcome of active movement of organisms in response to shifts in habitat quality (Mendonça et al., 2015; Picapedra et al., 2015) or passive vertical transport generated by mixing events (Kramer et al., 1997).

Both abiotic and biotic variables interact to determine zooplankton distribution in lakes. Predation by fish and invertebrates (Chaoborus) and competition for resources affect patterns of spatial segregation and succession of zooplankton communities (Zaret and Suffern, 1976; Demott, 1989; Dawidowicz et al., 1990; Wissel et al., 2003). These selective 
pressures induce behavioural changes in organisms by displacing them from optimal to suboptimal habitats (Gliwicz, 1986). The location of refuges in deep water mediates the impact of biotic forces on zooplankton and helps shape the character of vertical distribution (Primicerio, 2000; Wissel et al., 2003).

Zooplankton vertical migration behaviour is an important ecological trait that enhances overall fitness of organisms (Enright, 1977; Williamson et al., 1996). The main driver of migratory activities is avoidance of capture from visually hunting fish (Zaret and Suffern, 1976). To minimize spatial overlap with competitors and predators, species may exploit different habitats (Primicerio, 2000). Thus, the specific depthlocation of a species is the outcome of trade-offs among several competing decisions on habitat choice (Brown, 1998; Lampert et al., 2003; Kessler and Lampert, 2004). Various theories suggest that organisms derive multiple advantages by optimizing their vertical locations in the water column to maximize fitness (Williamson et al., 1996; Pearre, 2003). Habitat stability may therefore promote a stabilizing effect on habitat use by organisms occupying specific habitats (Hanski, 1988).

Seasonal changes such as lake mixing and restratification are examples of physical upsets to habitat suitability. The resultant changes broaden the habitable volume and homogenize the water column occupied by organisms (Kramer et al., 1997). This ensures greater range of dispersion and consequently active segregation of species along the water column is curtailed (Kramer et al., 1997). Water movements generated by wind-induced turbulence overpower the swimming capabilities of organisms and spread organisms across an increased oxygenated volume (Spitael, 2007; Heald, 2015). This downward movement may heighten predation risk by exposing prey species to deep-dwelling predators. These seasonal oscillations can substantially alter the pattern of distribution (Burns and Mitchell, 1980; Primicerio, 2000; Wong et al., 2012) and compel organisms to occupy suboptimal depths at the expense of their overall fitness (Gliwicz, 1986; Lampert, 1993; Wissel and Ramcharan, 2003). The vast majority of deep African tropical lakes are permanently stratified with muted seasonality of their water columns (MacIntyre, 2012). The rare occurrence of full mixing events implies that active habitat selection of zooplankton will be less pervasive. This may possibly be the signature distribution of tropical zooplankton resident in deeper lakes.

Despite numerous studies on tropical African zooplankton, an extremely poor record of research work regarding their behavioural ecology exists. The impact of this research gap is even more apparent in the face of limnological regime shifts due to climate change and anthropogenic factors. Seasonal and multiyear studies are therefore required to improve our understanding of water column dynamics and responses of zooplankton organisms. The aim of this study therefore is to provide insight into how seasonality in water column structure in deep, stratified tropical African lakes affects distribution patterns of zooplankton.

\section{Materials and methods}

\subsection{Study site}

Lake Bosumtwi is a deep tropical lake. In recent times, it has shifted from holomictic - completely mixed to meromictic - partially mixed (Turner et al., 1996a; Puchniak et al., 2009). The closed-basin lake is characterized by a long water residence time and reduced flushing rates (Turner et al., 1996b). It occupies a nearly circular depression created by a meteorite that impacted the crater site 1.07 million years ago (Koeberl et al., 2007). The lake is located at $06^{\circ} 30^{\prime} \mathrm{N}$ and $01^{\circ} 25^{\prime} \mathrm{W}$ in the southcentral part of Ghana along the West African coast and lies in the path of the annual migration of the Intertropical Convergence Zone (ITCZ) (Koeberl et al., 2007) (Fig. 1). It has a crater diameter $10.5( \pm 0.5 \mathrm{~km})$, a lake-surface diameter of $8-8.5 \mathrm{~km}$, maximum depth of $78 \mathrm{~m}$ and surface area of $52 \mathrm{~km}^{2}$ (Koeberl et al., 1997). The lake's limnology is closely approximated to regional climate variability (Puchniak et al., 2009). The closedbasin structure means that it lacks inflow and outflow channels with water levels driven by the precipitation-evaporation balance and making the lake extremely sensitive to climate variability (Turner et al., 1996b). High rainfall seasonality is characterized by maximum precipitation in May/June with a secondary peak in September/October.

Mean conductivity, temperature, dissolved oxygen, salinity and $\mathrm{pH}$ within the top $30 \mathrm{~m}$ of the water column are $1150 \mu \mathrm{S} \mathrm{cm}^{-2}, 28.14{ }^{\circ} \mathrm{C}, 52.35 \%$ saturation, $0.32 \mathrm{psu}$ and 8.9 , respectively. The water column is stable with persistent stratification all year round and a permanently anoxic deep water underlying a mixed layer of variable depth and oxygen content (Puchniak et al., 2009). Mixing occurs strongly in August and weakly in January, but in certain years, the August circulation may be less prominent (Puchniak et al., 2009). Pronounced mixing events can liberate $\mathrm{H}_{2} \mathrm{~S}$ from deep water often leading to massive fish kills (Turner et al., 1996a; Puchniak et al., 2009). Entrainment of nutrient-rich hypolimnetic water triggers phytoplankton productivity during this period (Awortwi, 2009). Algal chlorophyll concentration in the mixed layer ranges between 0.002 and $32 \mu \mathrm{gL}^{-1}$ with an annual mean of $10 \mu \mathrm{g} \mathrm{L}^{-1}$. The phytoplankton community is dominated by Cyanobacteria (Poste et al., 2008; Awortwi, 2009). Previous studies characterized the zooplankton community as consisting of only nine taxa namely an endemic copepod Mesocyclops bosumtwii (Mirabdulayev et al., 2007), a dense Chaoborus larval assemblage, several rotifer species and a small-sized cladoceran Moina micrura (Kurz) (Sanful et al., 2012). The major rotifer species are Brachionus calyciflorus (Pallas) and Hexarthra intermedia (Wiszniewski). Species that are uncommon in the water column include Brachionus dimidiatus (Bryce), Keratella cochclearis (Gosse), Filinia pejleri (Hutchinson) and Filinia camascela (Myers) (Sanful et al., 2012). A seasonal band of green and purple sulphur bacteria peaks in metalimnetic layers $(12.5-15 \mathrm{~m})$ at the hypoxic-anoxic interface between March and July.

\subsection{Zooplankton sampling}

Discrete quantitative samples on day-time vertical distributions were collected biweekly between January 2005 and December 2006 at an index central station $06^{\circ} 30^{\prime} \mathrm{N}$ and $01^{\circ} 25^{\prime} \mathrm{W}$ between $11 \mathrm{~h}: 30 \mathrm{~min}$ and $00 \mathrm{~h}: 30 \mathrm{~min}$. The limnological season was classified as stratified (most months), mixing (January, July, August) and restratifying (September and October). Samples were collected from eleven discrete depths as follows: surface (0), 1, 2, 5, 8, 10, 12.5, 15, 20, 25 and $30 \mathrm{~m}$ of depth using a $6 \mathrm{~L}$ van Dorn water bottle to take 


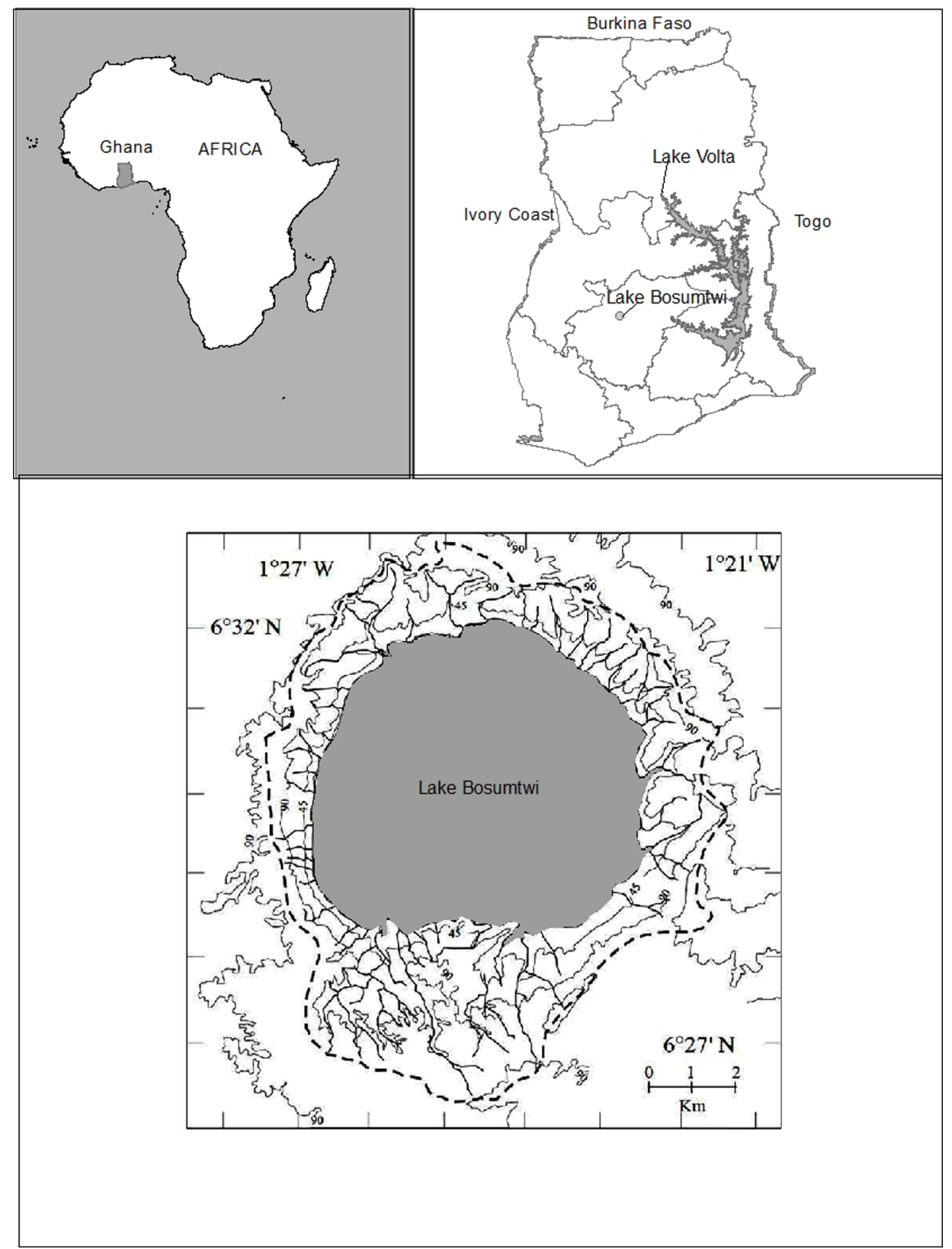

Fig. 1. Map of Lake Bosumtwi showing catchment boundary (broken lines) and its geographical location in the study country and continent. Lake map modified from Shanahan (2006).

triplicate samples at each depth. A total of $18 \mathrm{~L}$ of water containing zooplankton at each depth was filtered from the Van Dorn samples through a $25 \mu \mathrm{m}$ mesh. Based on prior knowledge of the water column structure, the sampling depths were segmented into epilimnetic (surface, $1,2,5 \mathrm{~m}$ ), metalimnetic $(8,10,12.5,15 \mathrm{~m})$ and hypolimnetic $(20,25$ and $30 \mathrm{~m})$ layers. Filtered zooplankton was preserved with $4 \%$ formalin.

\subsection{Diel (24-h) vertical migration (DVM) studies}

DVM studies were conducted on three dates corresponding to the stratified, mixing and restratifying events. Triplicate samples were collected with a 6-L Van Dorn sampler at eleven discrete depths compartmentalized into epilimnion (surface, 1 , $2,5 \mathrm{~m})$, metalimnion $(8,10,12.5,15 \mathrm{~m})$ and hypolimnion $(20$, 25 and $30 \mathrm{~m}$ ) at 6-h intervals beginning from $12 \mathrm{~h}: 00 \mathrm{~min}$ of the first day to $06 \mathrm{~h}: 00 \mathrm{~min}$ of the next day. Concurrent dissolved oxygen and temperature parameters were profiled with a Hydrolab $\mathrm{H}_{2} \mathrm{O}$ 6SBP multiprobe from a depth $50 \mathrm{~m}$ due to restricted cable of the Hydrolab. Notwithstanding, all three thermal layers were conveniently sampled with the $50 \mathrm{~m}$ mark well into the hypolimnion over the $78 \mathrm{~m}$ depth of the lake. Samples were stored in $125 \mathrm{~mL}$ glass bottles and preserved with $4 \%$ formalin. 


\subsection{Subsampling and enumeration procedures}

Zooplankton was counted from $5 \mathrm{~mL}$ subsamples. More than 200 individuals of the most common species were counted (McCauley, 1984). In contrast, $\geq 50$ individuals of the less common species were usually counted from several subsamples from a Sedgwick-Rafter counting chamber mounted on a Zeiss inverted microscope at $100 \times$ magnification.

\subsection{Physicochemical measurements}

The underwater light intensity was measured with a flatplate LI-COR 190R quantum sensor (LI-COR Biosciences, Lincoln NB). Measurements were taken at different depths from the surface to the depth where the light intensity was approximately $1 \%$ of surface irradiance, usually down to the metalimnion between 8 and $10 \mathrm{~m}$. A Hydrolab $\mathrm{H}_{2} \mathrm{O}$ 6SBP multiprobe (Hydrolab Corporation, Austin, Texas, 1991) was used to capture $50 \mathrm{~m}$-depth profiles of temperature and dissolved oxygen.

\subsection{Phytoplankton biomass measurement}

Phytoplankton biomass data were obtained from contemporaneous phytoplankton studies (Awortwi, 2009). Samples were usually concentrated into $125 \mathrm{~mL}$ subsamples after filtering through a mesh. Samples were usually obtained from a 6-L Van Dorn water bottle used to sample phytoplankton at biweekly intervals at ten discrete depths (surface, 1, 2, 5, 8, $10,12.5,15,20,30)$. These depths were similarly categorized into epilimnetic, metalimnetic and hypolimnetic layers. The subsamples were immediately preserved with $1 \mathrm{~mL}$ acid Lugol solution and subsequently stored in a dark, cool container for further analysis in the laboratory. Phytoplankton species were enumerated from settled $2 \mathrm{~mL}$ samples observed under an inverted Zeiss microscope in a $2 \mathrm{~mL}$ Utermohl chamber at $400 \times$ magnification and converted to wet weight biomasses through approximation of cell volume to geometrical formulae that best fits the shape of the cell.

\subsection{Data analysis}

Measured physicochemical parameters were categorized into independent group variables corresponding to distinct water layers. Seasonal variations were classified on the basis of stratified, mixing and restratifying conditions of the lake. The vertical density gradients of the zooplankton species served as the dependent variables. A two-way analysis of variance (ANOVA) and $t$-tests were used to examine whether dissolved oxygen, temperature and phytoplankton biomass varied significantly with depth and season. Data analysis and statistical tests were performed with Sigma Plot Version 10, SYSTAT 10 (Systat Software Inc.). Data were examined at the $5 \%$ level of statistical significance. The seasonal correspondence in depth distribution of physicochemical variables and zooplankton species densities were analyzed with both Spearman's Rank (pairwise) and Pearson's (listwise) correlations.

\section{Results}

\subsection{Vertical gradients in limnological variables}

Temperature, dissolved oxygen and phytoplankton biomass showed strong gradients between 10 and $15 \mathrm{~m}$ depth during the stratified period with a steep thermocline cooccurring with a strong oxycline in 2005 and 2006 (Fig. 2). Light distribution was bimodal with a highly illuminated upper epilimnion and darker metalimnion and hypolimnion (Tab. 1). Mean lake transparency was $1.6 \pm 0.41 \mathrm{~m}$ over the two years. The shallowest euphotic mean depth of $1.05 \pm 0.28 \mathrm{~m}$ was recorded during the restratifying period. During the stratified period, the mean epilimnetic, metalimnetic and hypolimnetic depths were 8,4 and $32 \mathrm{~m}$, respectively over the sampling depth of $50 \mathrm{~m}$ (Fig. 2). Lake stratification was characterized by well-defined gradients in light intensity, temperature, dissolved oxygen and phytoplankton biomass (Fig. 2). Statistically, during 2005 and 2006, the seasonal water column variation in temperature, dissolved oxygen, phytoplankton biomass and light intensity were all significant at the $5 \%$ probability level (Tab. 2).

\subsection{Interannual patterns of depth variability of limnological parameters}

Seasonal temperature, dissolved oxygen and phytoplankton biomass depth profiles in 2005 were correlated with that of 2006 by performing a Spearman's pairwise rank correlation analysis to compare the degree of similarity in the water column structure between the two years. All these parameters showed remarkable significant differences at $p<0.05$ (Tab. 3).

\subsection{Density gradients of zooplankton}

The summary statistics for the maximum and minimum densities of zooplankton and their respective means, standard deviations and significant differences among mean species densities are shown (Tab. 4). Adults, copepodites and nauplii of $M$. bosumtwii were predominant at all depths inhabited by zooplankton. However, most zooplankton species were highly concentrated in the epilimnion (Tab. 4). Overall, copepods showed the strongest gradients across all seasons decreasing dramatically in numbers from the epilimnion to the hypolimnion (Fig. 3). The hypolimnion was devoid of zooplankton at most times except Chaoborus, which showed an inverse distribution in the water column (Fig. 4). Statistically, adults of $M$. bosumtwii did not show any significant variation across depth and season at $p>0.05$, $n=15$ (Tab. 5). A similar pattern of distribution was exhibited by conspecifics where depth and seasonality of the water column structure did not exert any strong vertical density gradient on copepodites $(p>0.05, n=15)$ and nauplii $(p>0.05, n=15)$. All three developmental stages of $M$. bosumtwii all showed significant seasonal variations among the stratified, mixing and restratifying periods only in the epilimnion $(p<0.05, n=15)$. Differences in the metalimnion and hypolimnion over the same season were not significant at $(p>0.05, n=15)$. For B. calyciflorus, densities varied significantly in the epilimnion at $(p<0.05$, 

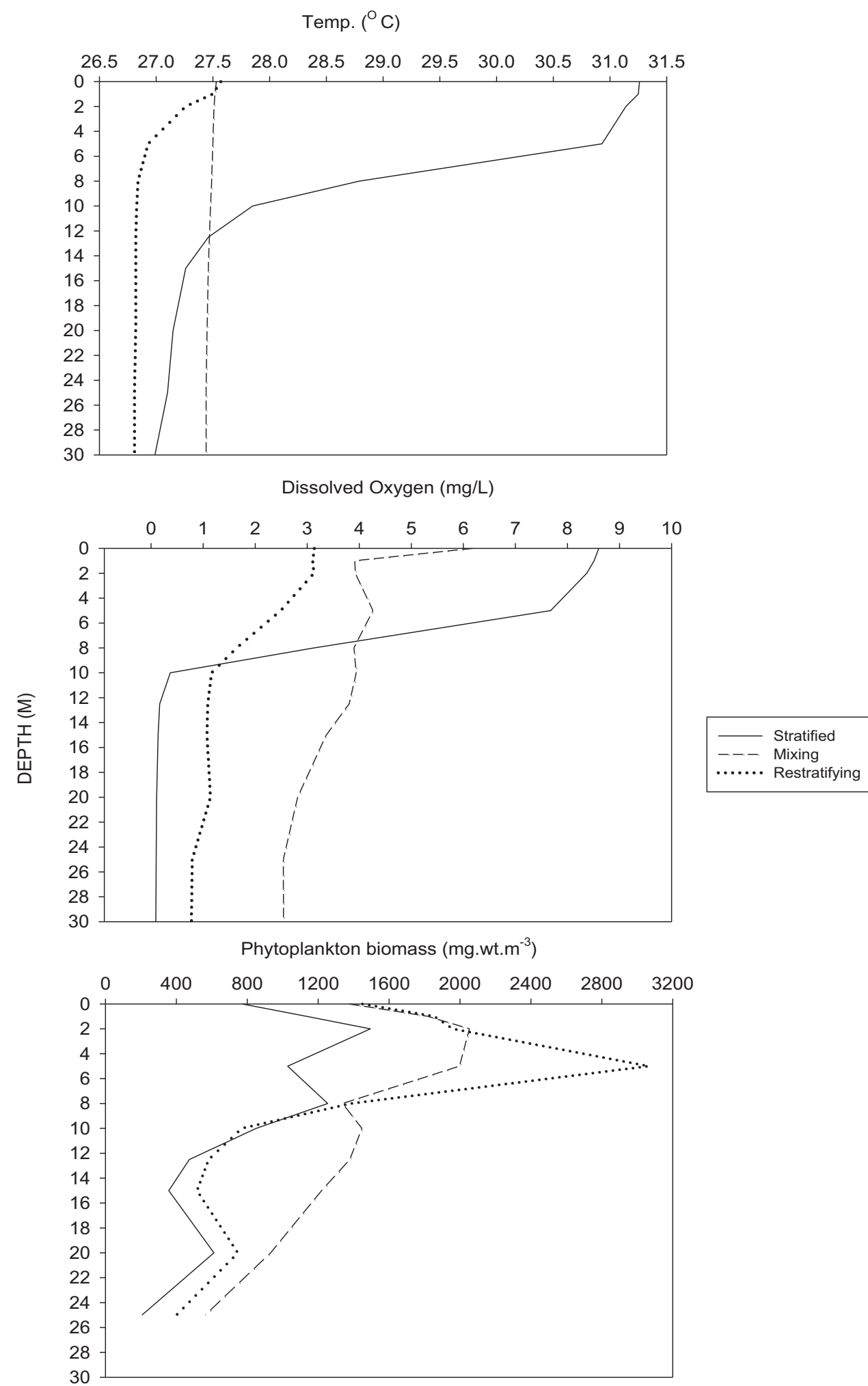

Fig. 2. Depth profiles of temperature, dissolved oxygen and phytoplankton biomass during stratified, mixing and restratifying periods.

$n=20)$ but variations in the metalimnion $(p>0.05, n=20)$ and hypolimnion $(p>0.05, n=20)$ were not significant. Both H. intermedia and Chaoborus did not exhibit any statistical relationship among depth and across seasons $(p>0.05, n=20)$ and $(p>0.05, n=20)$, respectively.

\subsection{Interannual patterns of depth variability of zooplankton species density}

Correspondence analysis showed that zooplankton species demonstrated significant interannual variability in the patterns 
Table 1. Summary statistics of maximum, minimum, mean and standard deviation of temperature, dissolved oxygen (DO) and phytoplankton biomass. Epilimnion $(n)=255$, metalimnion $(n)=153$, hypolimnion $(n)=153$. Probability values calculated for vertical differences in physicochemical parameters among epilimnion, metalimnion and hypolimnion. Sample size (n): temperature (20), DO (20), phytoplankton biomass (21), light intensity (7), Secchi depth (7).

\begin{tabular}{|c|c|c|c|c|c|c|c|c|c|c|c|c|c|}
\hline Parameter & \multicolumn{4}{|c|}{ Epilimnion } & \multicolumn{4}{|c|}{ Metalimnion } & \multicolumn{4}{|c|}{ Hypolimnion } & $P$-value \\
\hline Temperature $\left({ }^{\circ} \mathrm{C}\right)$ & 32.61 & 26.56 & 29.43 & 1.36 & 29.98 & 26.82 & 27.84 & 0.75 & 27.98 & 26.81 & 27.05 & 0.21 & $<0.05$ \\
\hline Phytoplankton biomass $\left(\mathrm{mg} \mathrm{wt} \mathrm{m}^{-3}\right)$ & 6375 & 208 & 2162 & 1264 & 3856 & 148 & 1238 & 799 & 2094 & 34 & 441 & 336 & $<0.05$ \\
\hline Light intensity $\left(\mu \mathrm{mol} \mathrm{s}{ }^{-1} \mathrm{~m}^{-2}\right)$ & 1050 & 6.5 & 265.77 & 299.96 & 0 & 0 & 0 & 0 & 0 & 0 & 0 & 0 & $<0.05$ \\
\hline
\end{tabular}

Table 2. Seasonal mean and standard deviation values of physicochemical variables in each stratum during 2005 and 2006 . Data for light intensity was not obtained in 2006 due to technical challenges with light meter. Epilimnion $(n)=255$, metalimnion $(n)=153$, hypolimnion $(n)=153$. Light intensity for stratified season $(n)=22$, mixing season $(n)=19$ and Secchi depth $(n)=4$.

\begin{tabular}{|c|c|c|c|c|c|c|c|c|c|}
\hline \multirow{2}{*}{$\begin{array}{l}\text { Physicochemical } \\
\text { variable }\end{array}$} & \multicolumn{3}{|c|}{ Stratified } & \multicolumn{3}{|c|}{ Mixing } & \multicolumn{3}{|c|}{ Restratifying } \\
\hline & Epi. & Meta. & Hypo. & Epi. & Meta. & Нypo. & Epi. & Meta. & Нyро. \\
\hline \multicolumn{10}{|l|}{2005} \\
\hline Temperature $\left({ }^{\circ} \mathrm{C}\right)$ & $30.37 \pm 1.01$ & \multicolumn{3}{|c|}{$27.59 \pm 0.3927 .11 \pm 0.1727 .46 \pm 0.55$} & \multicolumn{5}{|c|}{$27.29 \pm 0.3727 .08 \pm 0.2628 .59 \pm 1.3127 .04 \pm 0.2226 .8 \pm 0.01$} \\
\hline \multicolumn{2}{|c|}{ Phyto. biomass $\left(\mathrm{mg} \mathrm{wt}^{-3}\right) 688 \pm 367$} & $443 \pm 231$ & $208 \pm 201$ & $1644 \pm 1108$ & $1219 \pm 791$ & $667 \pm 546$ & $2953 \pm 1569$ & $9986 \pm 665$ & $470 \pm 359$ \\
\hline $\mathrm{DO}\left(\mathrm{mg} \mathrm{L}^{-1}\right)$ & $6.73 \pm 2.11$ & $0.59 \pm 0.61$ & $0.44 \pm 0.61$ & $3.63 \pm 0.63$ & $4.02 \pm 1.30$ & $1.50 \pm 1.51$ & $5.02 \pm 2.51$ & $0.91 \pm 1.01$ & $0.37 \pm 0.33$ \\
\hline Light intensity & \multicolumn{2}{|c|}{$195.50 \pm 260.990$} & 0 & \multicolumn{2}{|c|}{$344.3 \pm 328.460$} & 0 & 0 & 0 & 0 \\
\hline Secchi depth & $1.75 \pm 0.17$ & 0 & 0 & $1.35 \pm 0.1$ & 0 & 0 & $1.05 \pm 0.28$ & 0 & 0 \\
\hline \multicolumn{10}{|l|}{2006} \\
\hline Temperature $\left({ }^{\circ} \mathrm{C}\right)$ & $30.50 \pm 0.71$ & \multicolumn{3}{|c|}{$28.30 \pm 0.6927 .00 \pm 0.1928 .50 \pm 0.58$} & \multicolumn{5}{|c|}{$27.97 \pm 0.6727 .20 \pm 0.2928 .82 \pm 0.9327 .55 \pm 0.2127 .22 \pm 0.10$} \\
\hline Phyto. biomass ( $\mathrm{mg} \mathrm{wt}^{-3}$ & 3) $1970 \pm 1085$ & $726 \pm 312$ & $385 \pm 174$ & $2050 \pm 952$ & $1302 \pm 846$ & $396 \pm 219$ & $2744 \pm 1238$ & $81126 \pm 515$ & $447 \pm 283$ \\
\hline $\mathrm{DO}\left(\mathrm{mg} \mathrm{L}^{-1}\right)$ & $6.33 \pm 1.58$ & $2.92 \pm 2.66$ & $2.33 \pm 2.88$ & $6.88 \pm 1.69$ & $5.15 \pm 3.43$ & $2.36 \pm 2.69$ & $8.33 \pm 2.06$ & $1.76 \pm 1.65$ & $0.12 \pm 0.02$ \\
\hline Secchi depth & $1.70 \pm 0.2$ & 0 & 0 & $1.53 \pm 0.3$ & 0 & 0 & $1.35 \pm 0.19$ & 0 & 0 \\
\hline
\end{tabular}

Table 3. Spearman rank correlation comparing differences in seasonality of limnological variables in the water column between 2005 and 2006.

\begin{tabular}{llll}
\hline Parameter & Stratified & Mixing & Restratifying \\
\hline Dissolved oxygen & $0.53^{*}$ & $0.48^{*}$ & $0.84 *$ \\
Temperature & $0.89^{*}$ & $0.66^{*}$ & $0.94 *$ \\
Phytoplankton biomass & $0.42^{*}$ & $0.42^{*}$ & $0.64 *$ \\
\hline
\end{tabular}

$*$ Significance of the correlation and absence of $(*)$ shows that relationship is not significant. Number of observations for stratified $(n=43)$, mixing $(n=55)$, restratifying $(n=44)$.

of vertical distribution (Tab. 6). Most species showed significant correlations $(p<0.05)$ between the mixing and restratifying periods with values of correlation coefficients $\left(R^{2}\right)$ ranging from 0.24 for $M$. bosumtwii adults to 0.53 recorded for B. calyciflorus. There were no similarities in the vertical distribution profiles between the stratified periods in 2005 and 2006. Chaoborus movements in the water column showed dissimilar patterns from year to year with no correlations in the structure of distribution in the water column $(p>0.05)$. 
P.O. Sanful et al.: Ann. Limnol. - Int. J. Lim. 53 (2017) 293-307

Table 4. Summary statistics including maximum, minimum, mean and standard deviation of population densities of each species in the individual water stratum. Epilimnion $(n)=255$, metalimnion $(n)=153$, hypolimnion $(n)=153$.

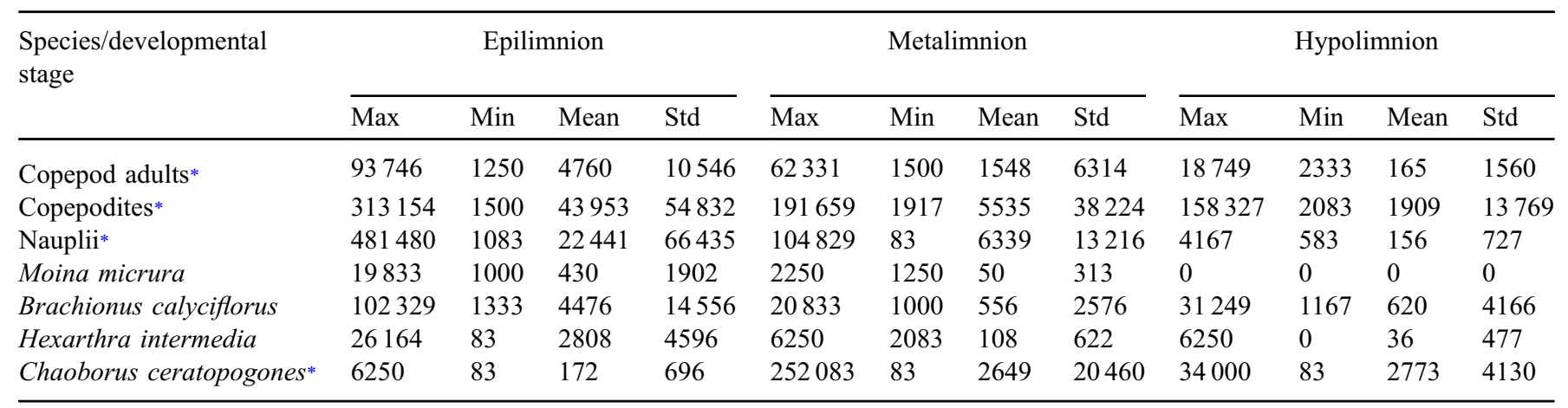

* Significance of mean species densities among epilimnion, metalimnion and hypolimnion at $p<0.05$.

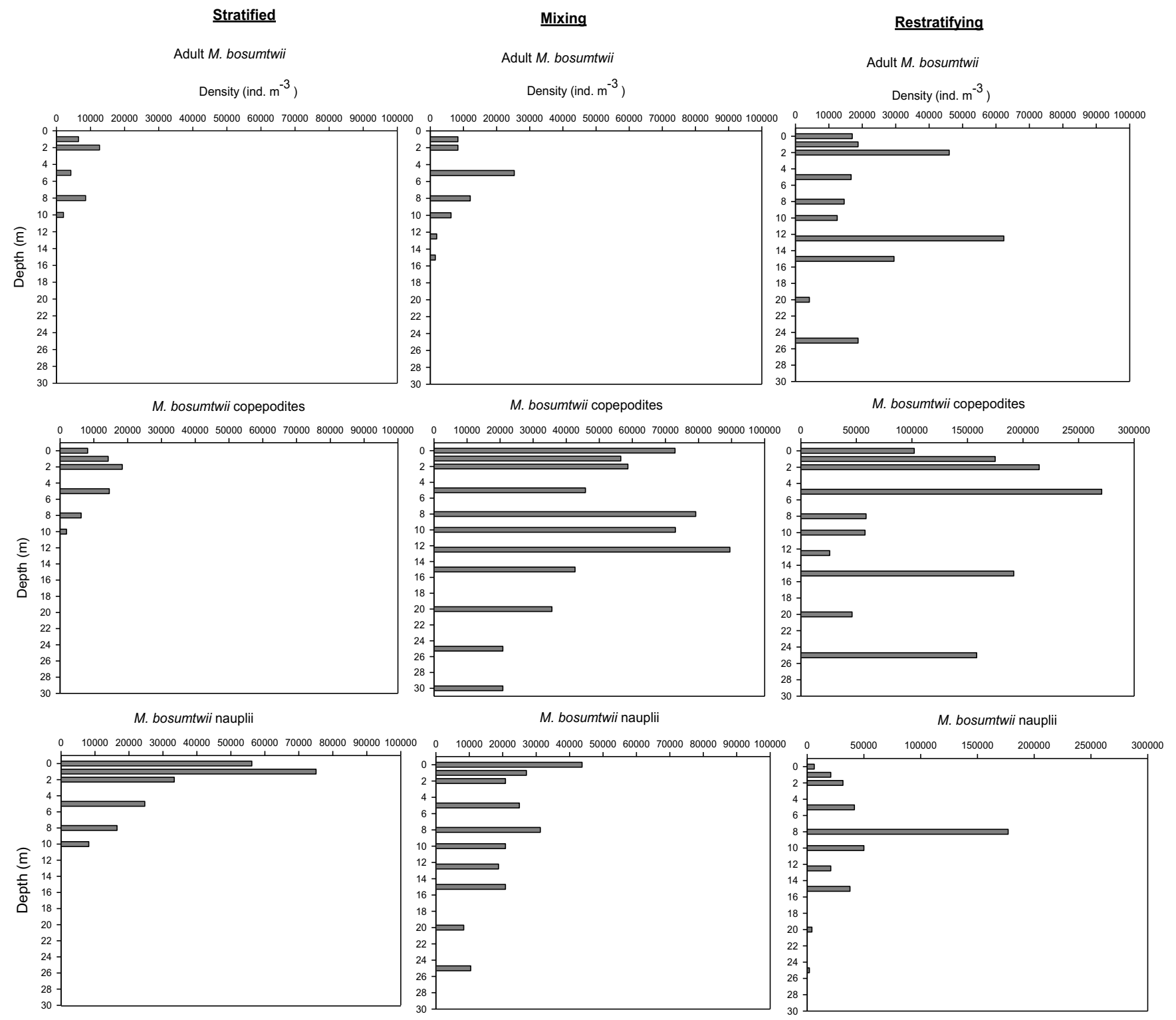

Fig. 3. Diurnal depth distribution of adults, copepodites and naupliar stages of the copepod M. bosumtwii during stratified, mixing and restratifying periods. 


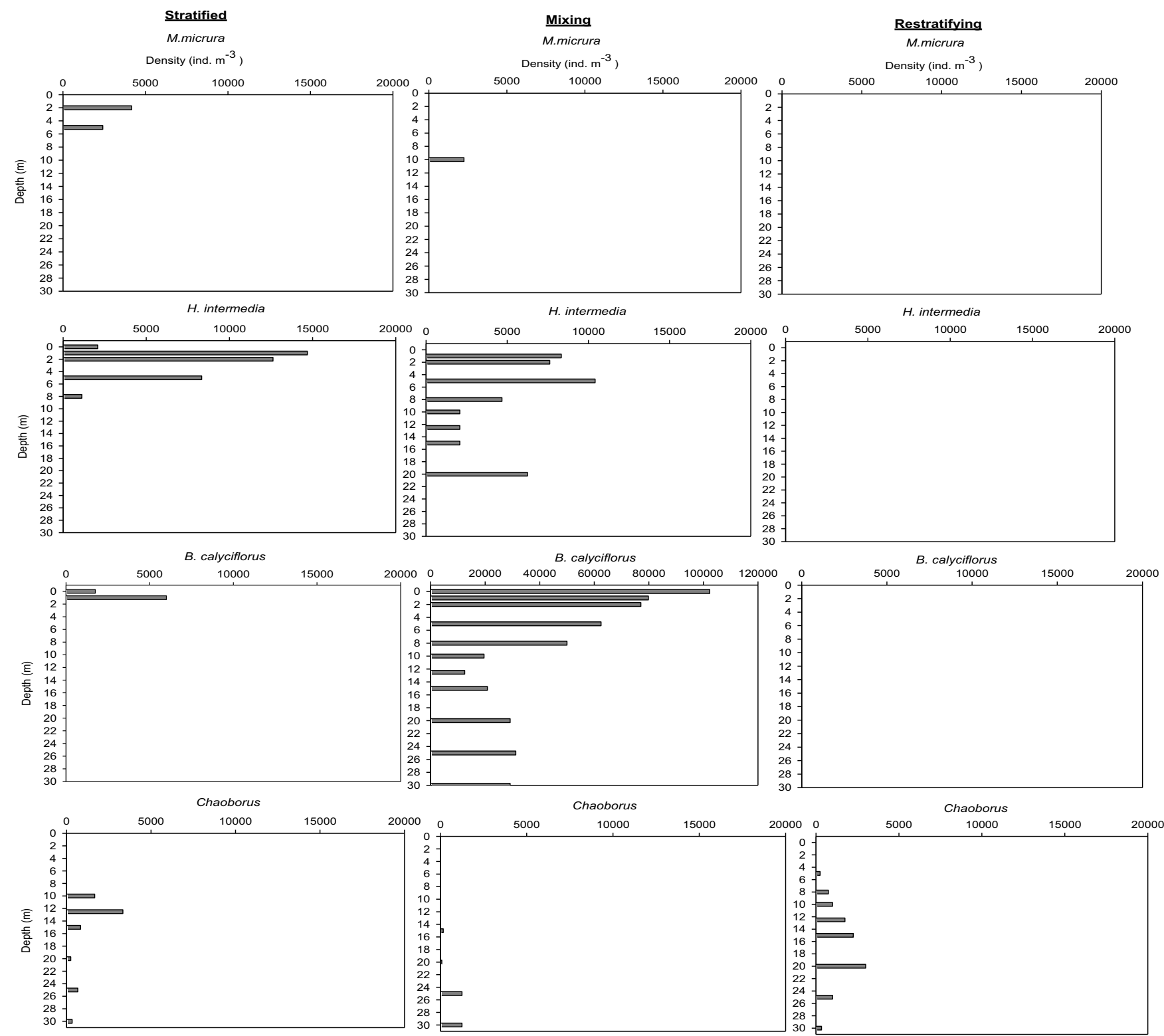

Fig. 4. Diurnal depth distribution of M. micrura, H. intermedia, B. calyciflorus and Chaoborus during stratified, mixing and restratifying periods.

Table 5. Variation of mean densities of zooplankton taxa within epilimnion, metalimnion and hypolimnion at $p<0.05$ significance level. Sample size $(n)$ is given in bracket. NS - not significant.

\begin{tabular}{llll}
\hline Parameter & Stratified & Mixing & Restratifying \\
\hline Copepod adults & NS & NS & NS \\
Copepodites & NS & $p<0.05(15)$ & $p<0.05(12)$ \\
Nauplii & NS & $p<0.05(15)$ & NS \\
B. calyciflorus & $p<0.05(12)$ & NS & NS \\
H. intermedia & NS & NS & NS \\
Chaoborus & NS & NS & NS \\
\hline
\end{tabular}




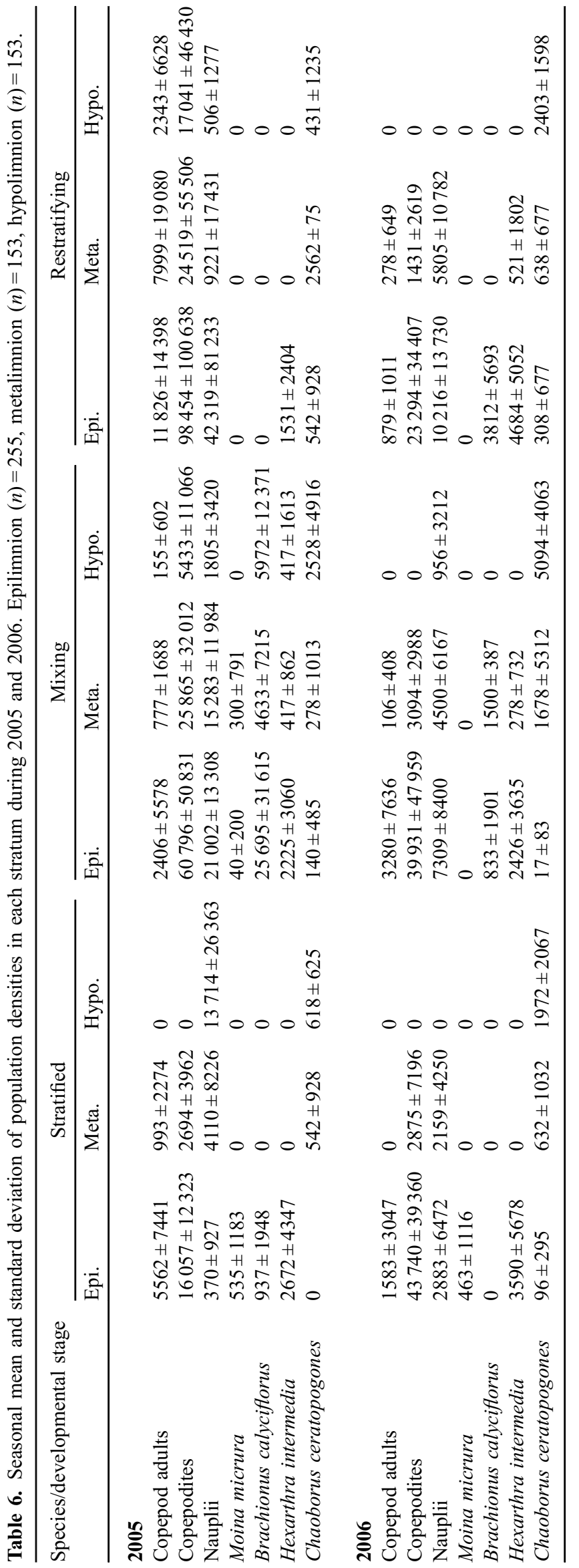

\subsubsection{Variation of zooplankton species densities with limnological variables}

Densities of adults, copepodites and nauplii stages of M. bosumtwii were positively correlated with physicochemical variables and phytoplankton biomass profiles in the water column across all seasons and years (Tab. 7). An inverse relationship was observed by the Chaoborus distribution patterns with limnological variables and $H$. intermedia did not exhibit statistical relationships during the mixing season.

\subsection{Seasonality of DVM Patterns}

No zooplankton species and developmental stages of M. bosumtwii performed active day and night migration in the water column over the three limnological seasons (Figs. 5-7). Most species inhabited the epilimnion and metalimnion en masse throughout the period. Even though numbers of Chaoborus were relatively higher in surface waters at night, density-driven mass movements were not detected. A greater dispersion in the water column was, however, observed during the mixing period. The analyses of DVM patterns showed that temporal changes in the densities of individual species among the various water strata were weakly correlated and yielded poor statistical results (range of $R^{2}=0.14-0.89, p>0.05$ ).

\section{Discussion}

Lake Bosumtwi exhibited distinct limnological cycles and spatio-temporal dynamics of the water column. The significant depth of the lake permitted establishment of a thermal structure based on pronounced temperature and density gradients between water masses. These characteristics commonly depicted by stratified lakes feature a resource-rich, growthenhancing epilimnion and a deeper, resource-poor, growthlimiting hypolimnion separated by an intermediate metalimnion (Wetzel, 2001). Variations in the water column structure due to mixing and restratification cycles also occurred. Combined with stratification, they defined the seasonality of the lake. This seasonality of Lake Bosumtwi like most deep African lakes has prolonged stratification and collapse of thermal stability are only ephemeral (Puchniak et al., 2009; MacIntyre, 2012). The extended stratification period stabilized the water column and maintained consistent habitat conditions for zooplankton. The clear seasonal changes produced by these distinct lake events however yielded little impacts on patterns of zooplankton distribution.

The role of thermocline deepening and lake mixing in shaping distribution patterns of zooplankton is well-documented (Spitael, 2007; Cantin et al., 2011). Limnological seasonality was marked by reduced amplitude of water column dynamics through limited span in mixing and restratification processes. Lake mixing broadened the habitable volume for zooplankton by extending their range of distribution. This mainly occurred due to oxygenation of anoxic depths. The downward mixing of oxygen will also force Chaoborus to deeper depths to accomplish the same degree of refuge. Consequently oxygen has the effect of reducing predation by Chaoborus and therefore total predation by forcing Chaoborus down to deeper depths. The increased delivery of dissolved 
Table 7. Spearman rank correlation between species densities of zooplankton and limnological variables during 2005 and 2006.

\begin{tabular}{|c|c|c|c|c|c|c|c|c|c|}
\hline Species & \multicolumn{3}{|c|}{ Stratified } & \multicolumn{3}{|c|}{ Mixing } & \multicolumn{3}{|c|}{ Restratifying } \\
\hline Copepod adults & $0.57 *$ & $0.56^{*}$ & $0.56^{*}$ & $0.17 *$ & 0.08 & 0.04 & $0.33^{*}$ & $0.38^{*}$ & $0.49^{*}$ \\
\hline Copepodites & $0.74 *$ & $0.74 *$ & $0.56^{*}$ & $0.51 *$ & $0.19^{*}$ & $0.12^{*}$ & $0.58^{*}$ & $0.59 *$ & $0.66^{*}$ \\
\hline Chaoborus & $-0.61 *$ & $-0.59 *$ & -0.40 & -0.28 & $-0.17^{*}$ & $-0.53^{*}$ & $-0.05^{*}$ & $0.13^{*}$ & 0.03 \\
\hline \multicolumn{10}{|l|}{2006} \\
\hline Copepod adults & $0.37 *$ & $0.34 *$ & $0.33 *$ & $0.44 *$ & $0.34 *$ & 0.40 & $0.46^{*}$ & $0.46^{*}$ & $0.26^{*}$ \\
\hline Copepodites & $0.35^{*}$ & $0.49^{*}$ & $0.39 *$ & $0.49 *$ & $0.59 *$ & $0.37 *$ & $0.76^{*}$ & $0.75^{*}$ & $0.58 *$ \\
\hline
\end{tabular}

* Significance of the correlation and absence of $(*)$ shows that relationship is not significant. Number of observations for stratified $(n=44)$, mixing $(n=55)$, restratifying $(n=44)$.

oxygen to anoxic depths allowed copepods to also occupy deeper layers but this displacement was short-lived and less instructive. The increased dispersal of copepods could be explained by either active or passive mechanisms. However, because copepods did not previously inhabit deeper waters, their increased densities could be attributed entirely to vertical transport by water currents. The latter is supported by evidence of the role of physical forces in distributing zooplankton passively in the water column (Mavuti, 1992; Kramer et al., 1997; Kizito, 1998).

Knowledge of mechanisms underlying habitat selection is key to understanding zooplankton distribution. Majority of species stayed in the epilimnion and used this single habitat without migration to exploit other deep strata. The preference for the epilimnion may be adaptive permitting organisms to maximize growth and development potential (Threlkeld, 1980; Orcutt and Porter, 1983; Stich and Lampert, 1984). Constancy of the physical environment favoured continuous epilimnetic residence. This suppressed any possible alterations to distribution patterns of species. The position of organisms at any specific depth in a stratified lake is suggested as a tradeoff among conflicting decisions on habitat choice (Lampert, 2005). Persistence of zooplankton in the epilimnion may therefore confer an advantage on organisms because in deep water, growth and reproductive performance decline with decreasing temperature and food scarcity (Ringelberg, 2009). Spatial segregation with Chaoborus reduced predation risk on prey in the epilimnion. Coupled with poor food and growth conditions in the hypolimnion, descent by organisms was discouraged and severely restricted. Such situations commonly result in diminished zooplankton migration (Gliwicz and Pijanowska, 1988; Leibold, 1990; Lampert, 2005). The lack of migration further highlights the importance of predation in determining prey distribution (Zaret and Suffern, 1976; Pearre, 2003; Mendonça et al., 2015). It is possible that zooplankton may develop specialized abilities to use the epilimnion more efficiently due to consistency in habitat use. Temporal changes in the size of predator populations and limiting food resources may undermine the adaptation process by increasing predation and competition. This may compel organisms to migrate deeper into suboptimal conditions in the hypolimnion, therefore altering community structure (Zaret and Suffern, 1976; Primicerio, 2000). However, these biotic forces were weakened by extensive spatial overlaps between prey and invertebrate predators.

Only Chaoborus carried out "normal" DVM - daytime descent into deeper depths and night-time ascent to surface layers - on a diel cycle. This movement was detected rather on a limited scale. The DVM activity undertaken by Chaoborus prevented coexistence with its prey populations mainly confined to the epilimnion. Chaoborus ascent at night led to a shared habitat with prey organisms that did not depart from surface waters even though the presence of their predators increased risk of capture. The lack of response from prey demonstrates that the densities of predators are either well below the threshold required to induce migratory activity or prey may compensate for mortalities with increased reproductive potential (Fejes et al., 2003). For prey to be forced to abandon a preferred habitat, predation pressure must exceed a specific threshold to trigger descent (Zaret and Suffern, 1976). Non-migrant animals may suffer high rates of respiration and mortalities in surface waters but could balance these losses with high food supply and increased fecundity (Dawidowicz and Loose, 1992). This behaviour is complemented by stability of the epilimnetic habitat, which has adaptive value for optimizing metabolic and reproductive fitness (Hanski, 1988). The lack of migration further suggests that predatory losses of species due to fish are weak or they would be higher if they migrated down during the day and be exposed to Chaoborus.

Competition is an important determinant of zooplankton distribution (Nogrady et al., 1993). There was high overlap in habitat use among competing herbivore species given the 

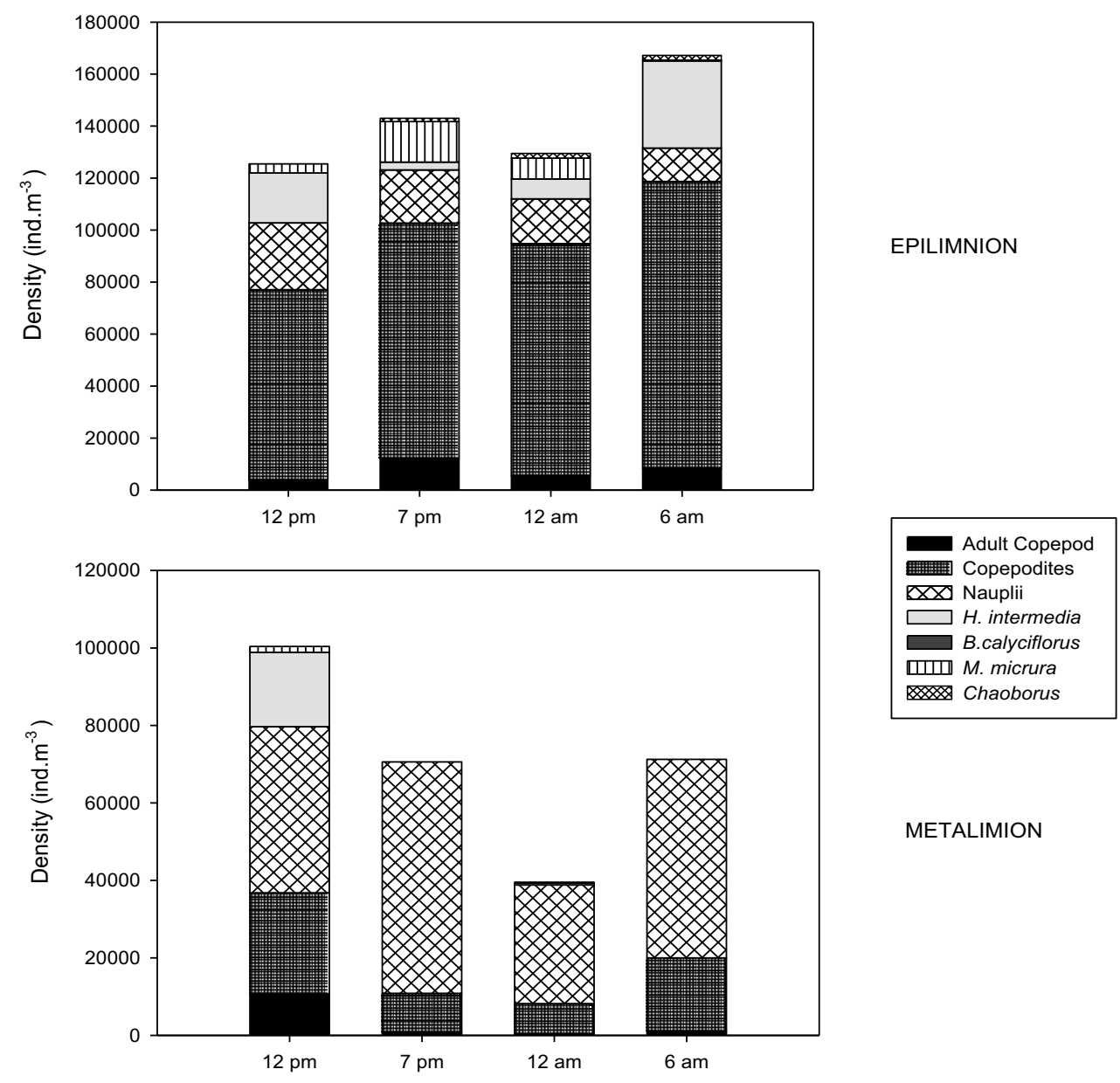

METALIMION

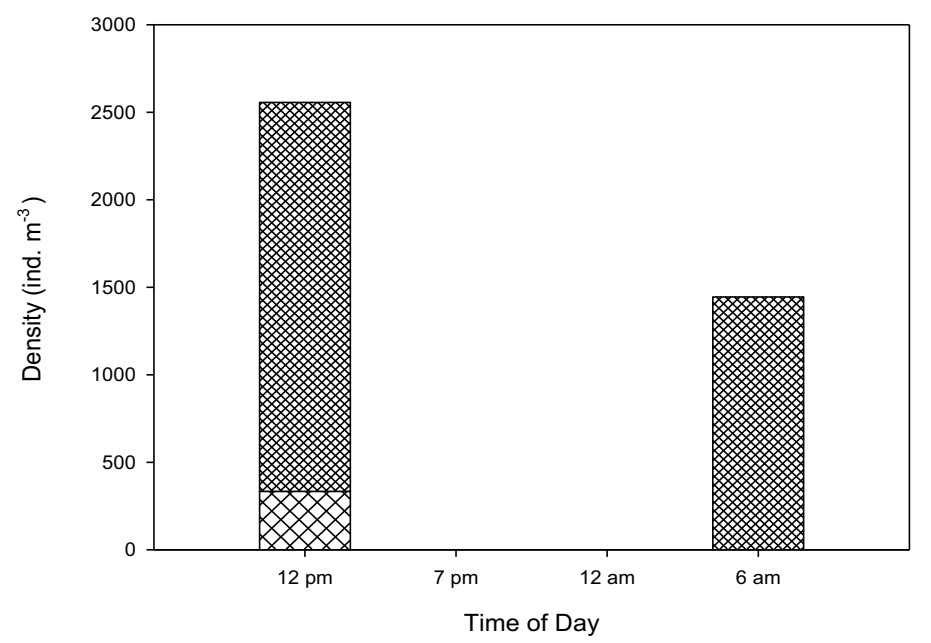

HYPOLIMNION

Fig. 5. Diel vertical migration (DVM) patterns of zooplankton taxa during the stratified season.

degree of stability in the habitat. This degree of spatial overlap increases vulnerability of prey to predation and intensifies interspecific competition (Quintana et al., 2015). Competitors often limit overlaps in habitat use to overcome inequalities in competitive abilities (Nogrady et al., 1993; Primicerio, 2000). The influence of competition on prey species may be evident in the distribution pattern of key herbivores in the lake. Major herbivore species, mainly B. calyciflorus, H. intermedia and
M. micrura, compete for limited quantities of edible algal food, given the abundance of toxic cyanobacteria in the phytoplankton community (Awortwi et al., 2015). These types of organisms are also heavily preyed upon by Chaoborus (Moore and Gilbert, 1987; Moore et al., 1994) and the interactions can contribute substantially to temporal and spatial structuring of zooplankton communities (Miller and Kerfoot, 1987; Rothhaupt, 1990). Larger organisms are predation-prone due 


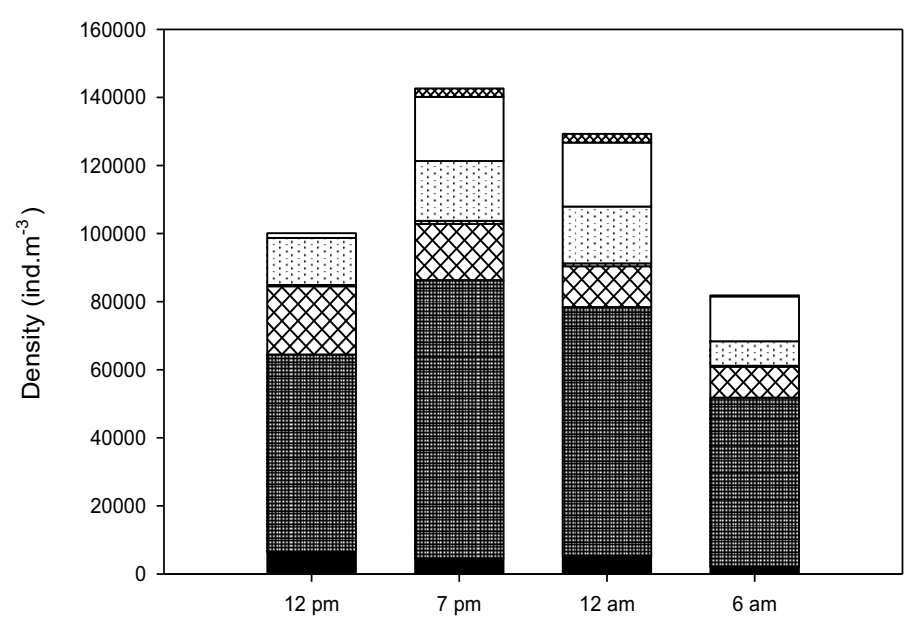

EPILIMNION

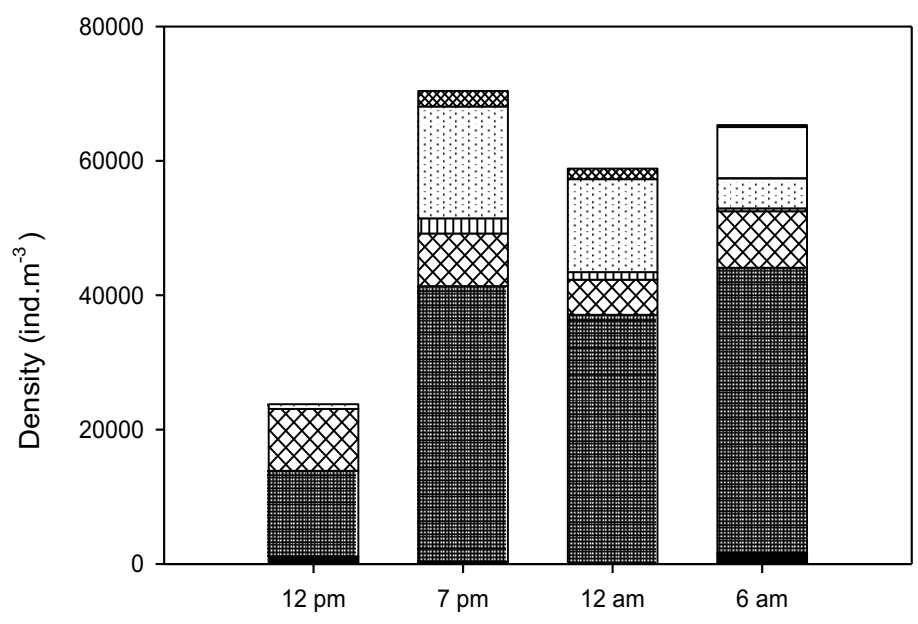

METALIMNION

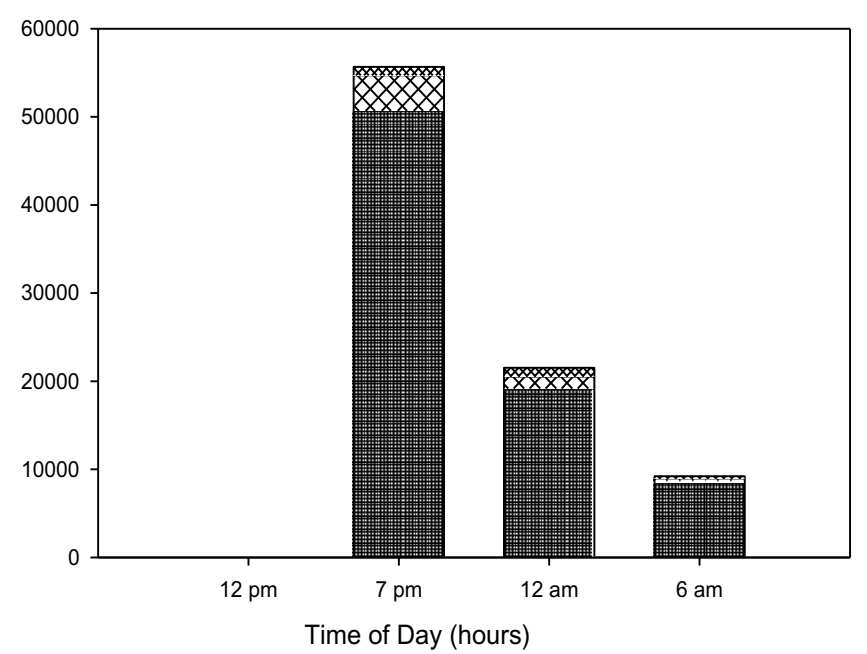

HYPOLIMNION

Fig. 6. Diel vertical migration (DVM) patterns of zooplankton taxa during the mixing season.

to the increased visibility to fish feeders (Zaret and Suffern, 1976; Stich and Lampert, 1981; Gliwicz, 1986) but small-sized organisms such as rotifers may escape detection and thereby reduce losses (Zaret, 1980; Gliwicz and Pijanowska, 1988). This explains why rotifers selected to stay in the epilimnion for most part of the year despite the strong presence of Chaoborus.

Fish predation is largely regarded as a proximate factor in altering patterns of distribution and overall structure of zooplankton communities (Zaret and Suffern, 1976). Due to the absence of fish data, the influence of fish predation on Chaoborus could not be well accounted for. However, the suspicion is that the dominant native haplochromine fishes mainly composed of cichlids may exploit zooplankton inefficiently because of the low visibility, which restricts their feeding on larger organisms like Chaoborus. Haplochromines are reported to be facultative zooplanktivore sight feeders 


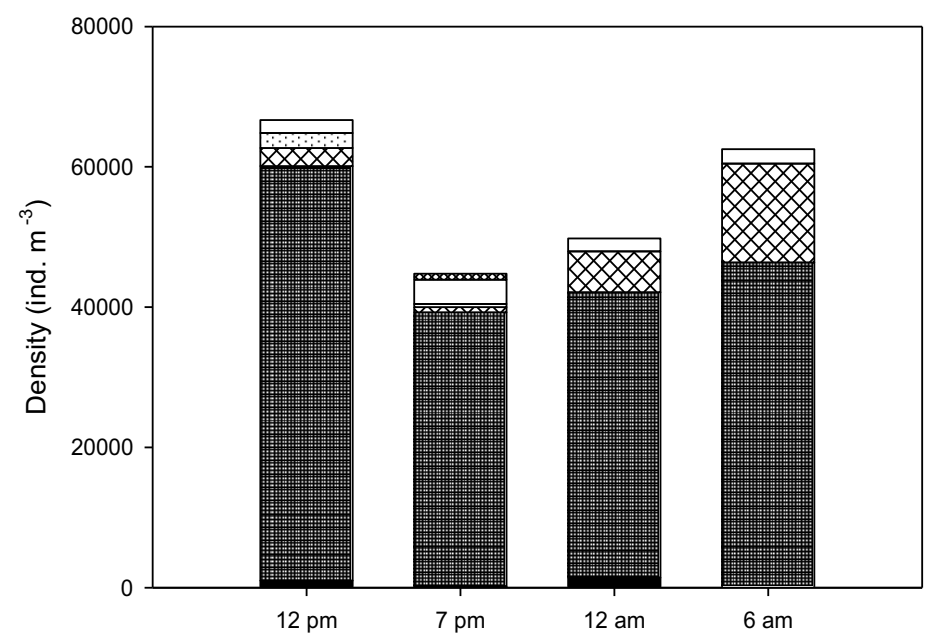

EPILIMNION
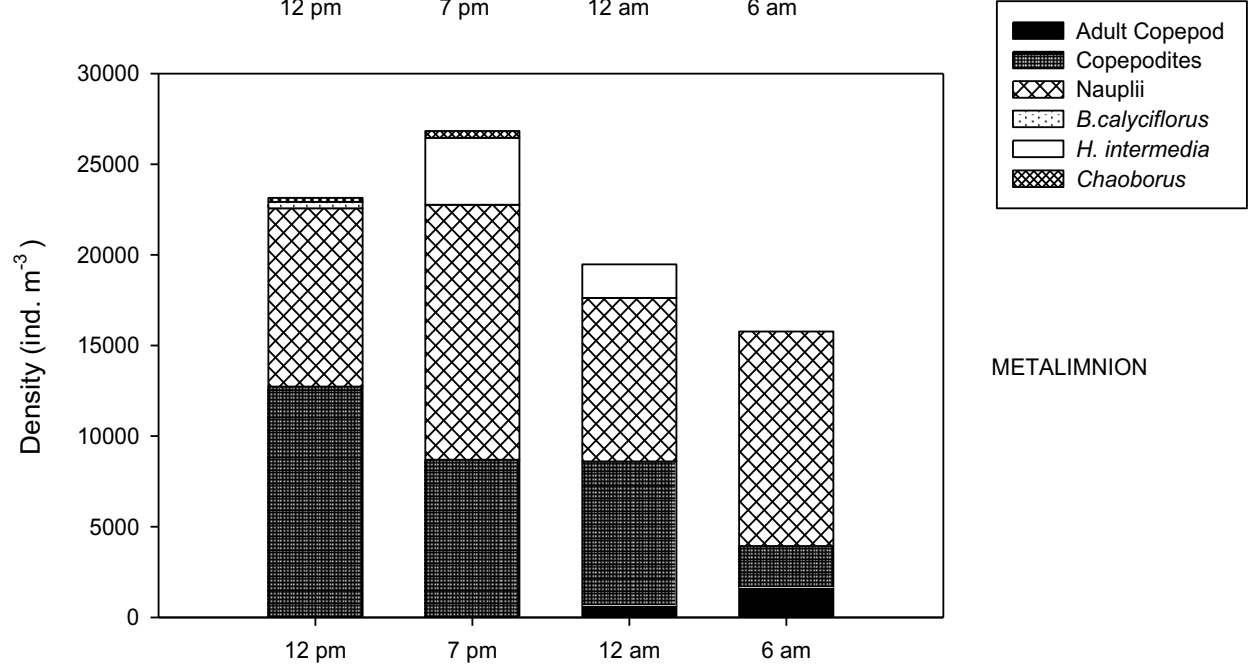

METALIMNION

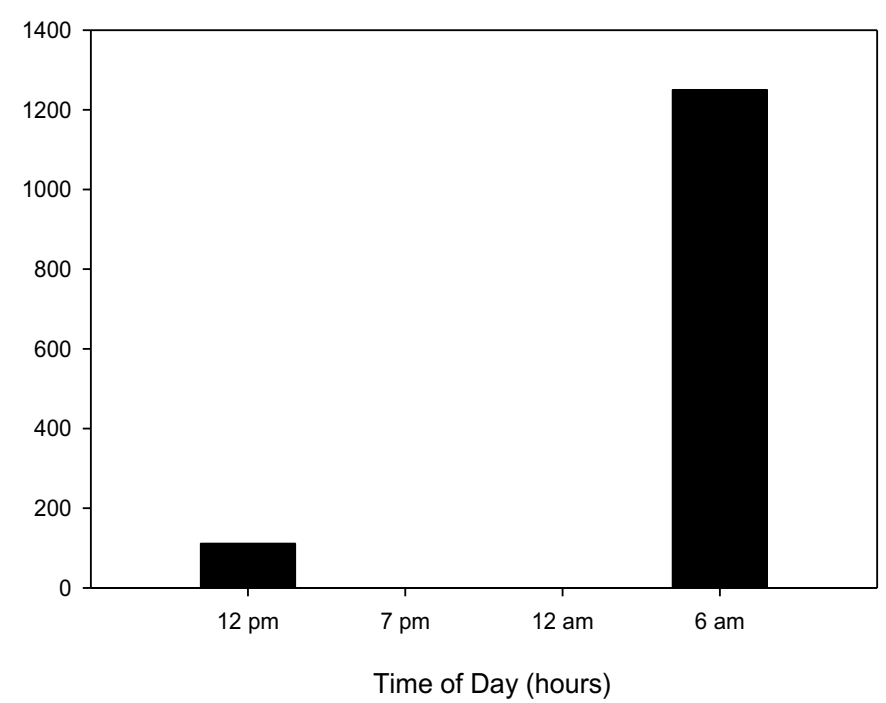

HYPOLIMNION

Fig. 7. Diel vertical migration (DVM) patterns of zooplankton taxa during the restratifying season.

(Poste et al., 2008) and in Bosumtwi, detection is limited by high phytoplankton turbidity due to large unconsumed biomass controlled by cyanobacteria (Awortwi et al., 2015). Low fish predation may give prominence to Chaoborus in regulating distribution patterns in the lake as has been noted by Lagergren et al. (2008) who documented the control exerted by invertebrate predators in DVM of other zooplankton. There is further evidence to suggest that at high fish population densities, feeding patterns of pelagic zooplanktivores may alter zooplankton community structure providing evidence for strong selective 
pressures to induce migratory behaviour (Hecky, 2006). This tendency may, however, be weakened by the high spatial segregation between Chaoborus and the fish community living in the mixed layer. The absence of strong planktivory often accounts for the lack of migratory activity in prey (Dini et al., 1993) although hypoxia/anoxia below the mixed layer may also be a barrier to migration if species are not adapted to such conditions. Chaoborus is an example of species adapted to low oxygen, thus allowing them to have a refuge from predation (Gade, 1985; Hazanato, 1992).

\section{Conclusion}

In conclusion, Lake Bosumtwi possessed a water column that displayed significant variation in depth but limited seasonality. Low variability in vertical distribution patterns of zooplankton was associated with equally low seasonal variation in water column structure. Habitat consistency restricted most populations to the epilimnion and this may be evidence of lack of strong selective pressures to alter habitat choice and habitat use. Chaoborus performed discernible DVM. The strategies for coexistence included spatial segregation and temporal overlaps of prey with predators and maintenance of low densities of herbivores.

Acknowledgements. This research was supported by NSERC (Canada), KNUST, University of Waterloo, (UW), DFAIT (Canada), International Society of Limnology (SIL) and the Lake Bosumtwi Research Project. We thank Dr. Megan Otu, Prof. S.K. Danuor, Fredua Agyeman, John Bilson, Yaw Manu and Prof. Roland Hall. We thank Dr. Mary Antwi (UENR) for redrawing the maps.

\section{References}

Andersen V, Nival P. 1991. A model of the diel vertical migration of zooplankton based on euphausiids. J Mar Res 49: 153-175.

Awortwi FE. 2009. Spatio-Temporal Variability of Phytoplankton Species Composition, Biomass and Primary Productivity of Lake Bosomtwe (Ghana). Ph.D. Thesis Dissertation. Kwame Nkrumah University of Science and Technology, Ghana.

Awortwi FE, Frempong E, Aikins SA, Hecky RE, Hall RI, Puchniak M. 2015. The relationship between mixing and stratification regime on the phytoplankton of Lake Bosomtwe (Ghana), West Africa. West Afr J Appl Ecol 23: 43-62.

Bini LM, Bonecker CC, Lansac-Tôha FA. 2001. Vertical distribution of rotifers on the Upper Paraná River floodplain: the role of thermal stratification and chlorophyll a. Stud Neotrop Fauna Env Lisse 36: 241-246.

Brown JS. 1998. Game theory and habitat selection. In: Dugatkin LA, Reeve HK, eds. Game theory and animal behaviour. Oxford University Press, Oxford, 188-220.

Burks RL, Lodge DM, Jeppesen E, Lauridsen TL. 2002. Diel horizontal migration of zooplankton: costs and benefits of inhabiting the littoral. Freshw Biol 47: 343-365.

Burns CW, Mitchell SF. 1980. Seasonal succession and vertical distribution of zooplankton in Lake Hayes and Lake Johnson. $N Z J$ Mar Freshw Res 14: 189-204.

Cantin A, Beisner BE, Gunn JM, Prairie YT, Winter JG. 2011. Effects of thermocline deepening on lake plankton communities. Can $J$ Fish Aquat Sci 68: 260-276.

Dawidowicz P, Loose CJ. 1992. Metabolic costs during predatorinduced diel vertical migration of Daphnia. Limnol Oceanogr 37: $1589-1595$.
Dawidowicz P, Pijanowski J, Ciechomski K. 1990. Vertical migration of Chaoborus larvae is induced by the presence of fish. Limnol Oceanogr 35: 1631-1637.

Demott WR. 1989. The role of competition in zooplankton succession. In: Sommer U, ed. Plankton ecology: succession in planktonic communities. Springer, Berlin-Heidelberg, 195-252.

Dini M, Soranno PA, Scheuerell M, Carpenter SR. 1993. Effects of predators and food supply on diel vertical migration of Daphnia. In: Carpenter SR, Kitchelle JF, eds. Trophic cascade in lakes. Cambridge University Press, Cambridge, 153-171.

Enright JT. 1977. Adaptive significance and timing. Selective advantage. A metabolic model. Limnol Oceanogr 22: 856-872.

Fejes E, Birbaum J, Gelwick F, Roelke D. 2003. Vertical distribution of herbivorous zooplankton in a well-mixed lake system in which the main predator is a non-selective filter-feeding fish. $J$ Freshw Ecol 18: 333-336.

Gade G. 1985. Anaerobic energy metabolism. In: Hoffman KH, ed. Environmental physiology and biochemistry of insects. New York: Springer-Verlag, pp. 119-136.

Gliwicz ZM. 1986. Predation and the evolution of vertical migration in zooplankton. Nature 320: 746-748.

Gliwicz ZM, Pijanowska J. 1988. Effect of predation and resource depth distribution on vertical migration of zooplankton. Bull Mar Sci 43: 695-709.

Hanski I. 1988. Preface. Ann Zool Fennici 25: 2-4.

Hansson L-A, Becares E, Fernádez-Aláez M, Fernádez-Aláez C, Kairesalo T, Miracle M, Romo S, Stephen D, Vakkilainen K, van de Bund W, van Donk E, Moss B. 2007. Relaxed circadian rhythm in zooplankton along a latitudinal gradient. Oikos 116: 585-591.

Hazanato T. 1992. Direct and indirect effects of low oxygen layers on zooplankton communities. Arch Hydrobiol 35: 87-98.

Heald E. 2015. Experimental mixing in a north temperate lake: examination of variability in spatial autocorrelation of fish and zooplankton populations. Ph.D. Thesis Dissertation. University of Minnesota, USA.

Hecky RE. 2006. ICDP Bosumtwi baseline limnological survey and early results of limnological studies funded by the NSERC. Technical Report.

Kessler K, Lampert W. 2004. Fitness optimization of Daphnia in a trade-off between food and temperature. Oecologia 140: 381-387.

Khalifa N, El-Damhogy KA, Fishar MR, Nasef AM, Hegab MH. 2015. Vertical distribution of zooplankton in Lake Nasser. Egypt $J$ Aquat Res 41: 177-185.

Kizito YS. 1998. Studies of the zooplankton of two Western Ugandan crater lakes, Nkuruba and Nyahira, with special emphasis on the bionomics and productivity of cyclopoids. Brussels: Royal Academy of Sciences, $98 \mathrm{p}$.

Koeberl C, Bottomley RJ, Glass BP, Storzer D. 1997. Geochemistry and age of Ivory Coast tektites and microtektites. Geochim Cosmochim Acta 61: 1745-1772.

Koeberl C, Milkereit B, Overpeck JT, Scholz CA, Amoako PYO, Boamah D, Danuor S, Karp T, Kueck J, Hecky RE, King JW, Peck JA. 2007. An international and multidisciplinary drilling project into a young complex impact structure: the 2004 ICDP Bosumtwi Crater Drilling Project - an overview. Meteorit Planet Sci 42: 483-511.

Kramer DL, Rangeley RW, Chapman LJ. 1997. Habitat selection patterns of spatial distribution from behavioural decisions. In: Godin J-G, ed. Behavioural ecology of teleost fishes. Oxford University Press, Oxford, 37-80.

Lagergren R, Leberfinger K, Stenson JAE. 2008. Seasonal and ontogenetic variation in diel vertical migration of Chaoborus flavicans and its effect on depth-selection behavior of other zooplankton. Limnol Oceanogr 53: 1083-1092. 
Lampert W. 1993. Ultimate causes of diel vertical migration of zooplankton: new evidence for the predator-avoidance hypothesis. Arch Hydrobiol 39: 79-88.

Lampert W. 2005. Vertical distribution of zooplankton: density dependence and evidence for an ideal free distribution with costs. Biomed Biol 3: 1-12.

Lampert W, McCauley E, Manly BFJ. 2003. Trade-offs in the vertical distribution of zooplankton: ideal free distribution with costs? Proc Biol Sci 270: 765-773.

Leibold MA. 1990. Resources and predators can affect the vertical distributions of zooplankton. Limnol Oceanogr 35: 938-944.

MacIntyre S. 2012. Stratification and mixing in tropical African lakes. In: Bengtsson L, Herschy R, Fairbridge R, eds. Encyclopedia of lakes and reservoirs. Dordrecht: Springer, pp. 737-743.

Mavuti KM. 1992. Diel vertical distribution of zooplankton in Lake Naivasha, Kenya. Hydrobiologia 232: 31-41.

McCauley E. 1984. The estimation of the abundance of biomass of zooplankton in samples. In: Downing JA, Rigler RH, eds. A manual on methods for the assessment of secondary productivity in freshwaters. Oxford: Blackwell Scientific, pp. 228-265.

Mendonça MM, Picapedra PHS, Ferronato MC, Sanches PV. 2015. Diel vertical migration of predators (planktivorous fish larvae) and prey (zooplankton) in a tropical lagoon. Iher Sér Zool 105: 174-183.

Miller TE, Kerfoot WC. 1987. Redefining indirect effects. In: Kerfoot WC, Sih A, eds. Predation: direct and indirect impacts on aquatic communities. Hanover: University Press of New England, pp. 33-37.

Mirabdulayev IM, Sanful PO, Frempong E. 2007. Mesocyclops bosumtwii sp. nov. (Copepoda: Cyclopidae) from Ghana. Ann Zool 57: $377-383$.

Moore MV, Gilbert JJ. 1987. Age-specific Chaoborus predation on rotifer prey. Freshw Biol 17: 223-236.

Moore MV, Yan ND, Pawson T. 1994. Omnivory of the larval phantom midge (Chaoborus spp.) and its potential significance for freshwater planktonic food webs. Can J Zool 72: 2055-2065.

Nogrady T, Wallace RL, Snell TW. 1993. Rotifera, biology, ecology and systematic. The Hague: SBP Academic Publishers, 142 p.

Orcutt JD, Porter KG. 1983. Diel vertical migration by zooplankton: constant and fluctuating temperature effects on life history parameters of Daphnia. Limnol Oceanogr 28: 720-730.

Pearre S. 2003. Eat and run? The hunger/satiation hypothesis in vertical migration: history, evidence and consequences. Biol Rev 7: 81-79.

Picapedra PHS, Lansac-Toha FA, Bialetzki A. 2015. Diel vertical migration and spatial overlap between fish larvae and zooplankton in two tropical lakes, Brazil. Braz J Biol 75: 352-361.

Poste AE, Hecky RE, Muir D. 2008. Biomagnification of mercury in a West African crater lake (Lake Bosomtwe, Ghana). Verhand Int Verein Theor Angew Limnol 30: 647-650.

Primicerio R. 2000. Seasonal changes in vertical distribution of zooplankton in an oligotrophic, subarctic lake (Lake Takvatn, Norway). Limnologica 30: 301-310.

Puchniak MK, Awortwi FE, Sanful PO, Frempong E, Hall RI, Hecky RE. 2009. Effects of physical dynamics on the water column structure of Lake Bosomtwe/Bosumtwi, Ghana (West Africa). Verhand Int Verein Theor Angew Limnol 30: 1077-1081.

Quintana XD, Arim M, Badosa A, Blanco JM, Boix D, Brucet S, Compte J, Egozcue JJ, et al. 2015. Predation and competition effects on the size diversity of aquatic communities. Aquat Sci 77 : 45-57.

Ringelberg J. 2009. Diel vertical migration of zooplankton in lakes and oceans: causal explanations and adaptive significances. Dordrecht: Springer Science \& Business Media, 356 p.

Rothhaupt KO. 1990. Resource competition of herbivorous zooplankton: a review of approached and perspectives. Arch Hydrobiol 118: $1-29$.

Sanful PO, Frempong E, Aikins S, Hall RI, Hecky RE. 2012. Secondary production of Chaoborus ceratopogones (Diptera: Chaoboridae) in Lake Bosumtwi, Ghana. Aquat Insects 34: 115-130.

Shanahan T. 2006. West African monsoon variability from a highresolution paleolimnological record Lake Bosumtwi, Ghana. Ph.D. Thesis. University of Arizona, USA.

Spitael MS. 2007. The effects of physical variables on zooplankton distribution in stratified lakes. Ph.D. Thesis Dissertation. University of Minnesota, USA.

Stich HB, Lampert W. 1981. Predator evasion as an explanation of diurnal vertical migration by zooplankton. Nature 293: 396-398.

Stich HB, Lampert W. 1984. Growth and reproduction of migrating and non-migrating Daphnia species under simulated food and temperature conditions of diurnal vertical migration. Oecologia 61: 192-196.

Stratton MA, Kessler DH. 2007. The role of light and oxygen in Chaoborus punctipennis (Insecta: Diptera) diel vertical migration. J Freshw Ecol 22(1): 101-106.

Threlkeld S. 1980. Habitat selection and population growth of two cladocerans in seasonal environments. Am Soc Limnol Oceonogr Spec Symp 3: 346-357.

Turner BF, Gardner LR, Sharp WE. 1996a. The hydrology of Lake Bosumtwi, a climate sensitive lake in Ghana, West Africa. J Hydrol 183: 243-261.

Turner BF, Gardner LR, Sharp WE, Blood ER. 1996b. The geochemistry of Lake Bosumtwi, a hydrologically closed basin in the humid zone of tropical Ghana. Limnol Oceanogr 41: 14151424 .

Wetzel RG. 2001. Limnology: lake and river ecosystems. San Diego: Academic Press, 1001 p.

Williamson CE, Sanders RW, Moeller RE, Stutzman PL. 1996. Utilization of subsurface food resources for zooplankton reproduction; implications for diel vertical migration theory. Limnol Oceanogr 41: 224-233.

Winder M, Boersma M, Spaak P. 2003. On the cost of vertical migration: are feeding conditions really worse at greater depths? Freshw Biol 48: 383-393.

Wissel B, Ramcharan CW. 2003. Plasticity of vertical distribution of zooplankton in lakes with varies levels of colour. J Plankton Res 25: 1047-1057.

Wissel B, Yan ND, Ramcharan CW. 2003. Predation and refugia: implications for Chaoborus abundance and species composition. Freshw Biol 48: 1421-1431.

Wong KW, Yau EYW, Lie AAY. 2012. The seasonal distribution, diel vertical distribution and feeding behavior of Paraeuchaeta concinna in the shallow subtropical coastal waters of eastern Hong Kong. Aquat Biosyst 8: 28.

Zaret TM. 1980. Predation and freshwater communities. New Haven: Yale University Press, 187 p.

Zaret TM, Suffern JS. 1976. Vertical migration in zooplankton as a predator avoidance mechanism. Limnol Oceanogr 21: 804-813.

Cite this article as: Sanful PO, Aikins S, Hecky RE. 2017. Depth distribution of zooplankton in relation to limnological gradients under different stratification and interannual regimes in a deep, tropical crater lake. Ann. Limnol. - Int. J. Lim. 53: 293-307 